\title{
Effect of Series and Parallel Shading on the Photovoltaic Performance of Silicon Based Solar Panels
}

\author{
Shalaw Zrar Sdeeq, Aso Hamad Ameen and Fahmi Fariq Muhammad
}

\author{
Soft Materials and Devices Laboratory, Department of Physics, Faculty of Science and Health, Koya \\ University, Koya, Kurdistan Region, Iraq
}

\begin{abstract}
In this research work silicon based solar panels were used to investigate the impact of series and parallel shading on the photovoltaic performance of inorganic solar panels. The results showed that voltage, current and power of the solar panels were reduced upon shading the series and parallel cells. This decrement was seen to be larger for the series shading compared to that of the parallel shading. This was attributed to the adverse effect of the series resistance of the shaded cells, which is acted as a bottleneck in front of the passage of current. This was not very effective in the parallel shading because current is readily capable to pass through the illuminated parallel cells and neglect the pathway of parallel shaded cells. From the results, it was concluded that the lower performance of solar panels due to shading effect is because of the change in the internal resistance of the panels. This situation is possible to occur during daily life use of solar panels as a result of the shading by clouds, dusts or trees. Hence, considerable investigation towards solving this problem is of great importance.
\end{abstract}

Keywords: Solar panel, partial shading, photovoltaics, I-V characteristic.

\section{INTRODUCTION}

Solar cells [1-3] are devices used to realize a direct conversion of sunlight energy into electricity by means of a viable technology known as photovoltaic (PV) technology [4]. Silicon solar cells currently dominate the PV market, as they have demonstrated high power conversion efficiencies, up to $25 \%$, due to the excellent charge transport properties and environmental stability of high purity silicon [1]. In order to obtain a desired voltage and current, solar panels are made from series and parallel combinations of solar cells. The main problem that is faced with utilization of solar panels is to deal with the non-linear internal resistance of interconnected solar cells [5]. The maximum power from a solar panel can only be extracted when the internal resistance of the panel is equal to the load resistance. The problem become more complicated when the solar panel receives non-uniform irradiance $[6,7]$ or partially shaded due to tree shadow, surrounding buildings and clouds. It is known that the effect of shading parallel cells on the overall performance of solar panels is vital $[8,9]$, which in turn results in the increased cost of solar panel installation as a larger number of panels are required to provide the same performance as of the non-shaded panels. Therefore, it is quite important to understand the characteristics of solar panels under partially shading before their installation is carried out under various conditions. Analytical modeling [10] and simulation method [11] have been carried out to

*Address correspondence to this author at the Soft Materials and Devices Laboratory, Department of Physics, Faculty of Science and Health, Koya University, Koya, Kurdistan Region, Iraq; Tel: +96 47701935331;

E-mail: fahmi.fariq@koyauniversity.org, fahmi982@gmail.com investigate the effect of shadowing on the performance of silicon based solar panels. Hence, this research work was devoted to experimentally investigate the impact of shading series and parallel solar cells on the photovoltaic performance of silicon based solar panels.

\section{MATERIALS AND METHODS}

Two small solar panels (Leybold Didactic GMBH) with dimension of $25 \mathrm{~cm} \times 25 \mathrm{~cm}$, which can be connected in series or in parallel were used in the current study. In order to maintain a constant illumination over the surface of the cells and ruling out the impact of intensity variation, a lamp with white light source was used throughout the experiments. The light intensity was fixed at about $11.4 \mu \mathrm{W} / \mathrm{cm}^{2}$, while the current and voltage measurements were made by using digital multimeters. Figure $\mathbf{1}$ shows the experimental set up used in the investigations. A variable resistor was employed as a load during the data collection. The shading procedure was performed by means of opaque papers in a regular series and parallel shading of the cells.

The maximum power $\left(P_{\max }\right)$ delivered from the solar panels and the fill factor $(F F)$ were calculated by using the following formula:

$\mathrm{P}_{\max }=\mathrm{V}_{\max }{ }^{*} \mathrm{I}_{\max }$

$F F=P_{\max } /\left(V_{o c}{ }^{*} I_{s c}\right)$

Where, $V_{o c}$ and $I_{s c}$ are open circuit voltage and short circuit current of the solar panels, respectively. 


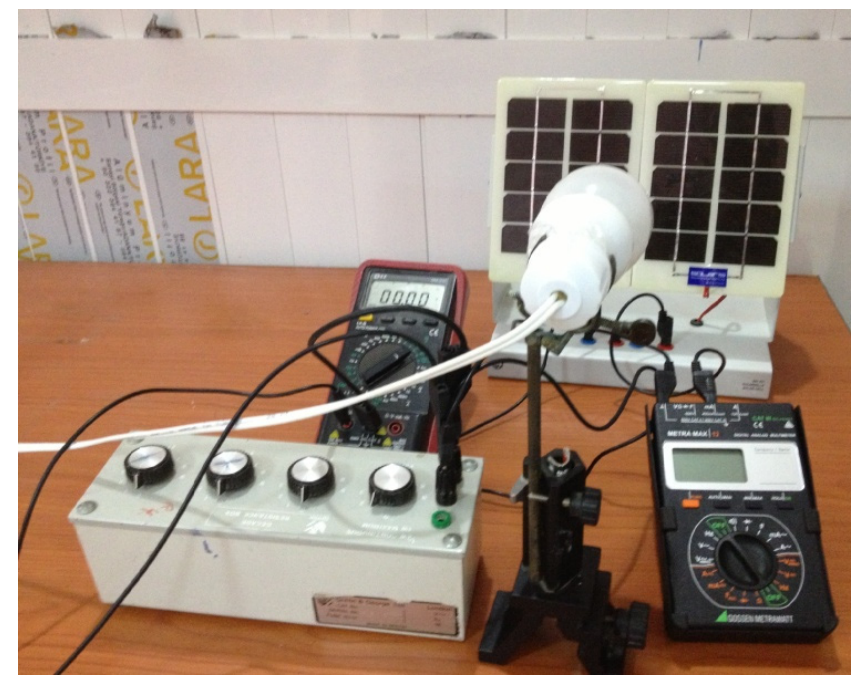

Figure 1: Experimental setup used for the photovoltaic investigation of non-shaded and shaded solar panels.

\section{RESULTS AND DISCUSSION}

Figure 2 shows the $I-V$ characteristic of the nonshaded solar panels, where $V_{O C}$ representing the open circuit voltage obtained when the load shows infinite resistance, and $I_{S C}$ denoting the short circuit current achieved when the load resistance is set to zero. It can be seen from the figure that the $I-V$ characteristic of solar panel demonstrates a non-linear behavior, which is the intrinsic property of solar cell devices [12]. The shape of the curve is close to a rectangular one, in which there is a relatively constant current over wide range of voltages. Beyond a specific voltage, where the maximum power can be delivered to the load, the current starts to decrease rapidly. This decrement in current is due to the high output load resistance in comparison to that of the internal resistance of the solar cell $[13,14]$. At the point where the internal and external resistances are equal, maximum power can be transfer into the output load. This power is known as $P_{\max }$, while its current and voltage is recognized as $I_{\max }$ and $V_{\max }$, respectively. By having the more rectangular

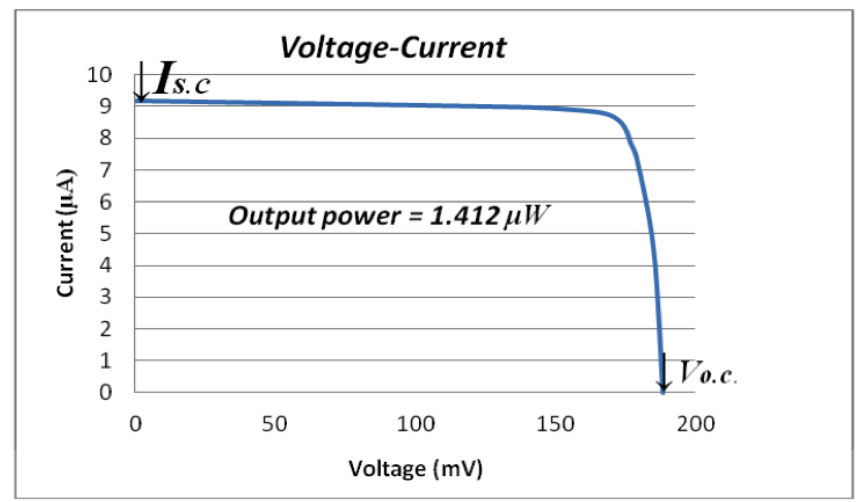

Figure 2: $I-V$ characteristic of non-shaded solar panels. shape of $I-V$ curves the more practical and efficient solar cell can be yield.

Figures 3, 4 and 5 show the $I-V$ characteristics of solar panels with two, four and six series cells shaded, respectively. It was noticed that the value of open circuit voltage, short circuit current and output power were decreased as follows; $V_{o c}$ has decreased from $188.3 \mathrm{mV}$ to $34.5 \mathrm{mV}$, and $I_{s c}$ decreased from $9.2 \mu \mathrm{A}$ to $1.7 \mu \mathrm{A}$, while $P_{\text {out }}$ was decreased from $1.412 \mu \mathrm{W}$ to $0.0213 \mu \mathrm{W}$. The large decrement in these parameters can be ascribed to the change in the internal arrangement of the solar cells constitute the panel, thereby deteriorating the non-linear internal resistance of the solar panel as a whole $[15,16]$. One can notice from Figure 3 that the shape of the $I-V$ curve is different from that of the non-shaded solar panel, indicating the effect of series shading on the performance of the panel. This can be simulated with a diode connected to the high series resistance, as the series resistance acts upon reducing the current flowing through the diode (consider the diode as an ideal solar cell).

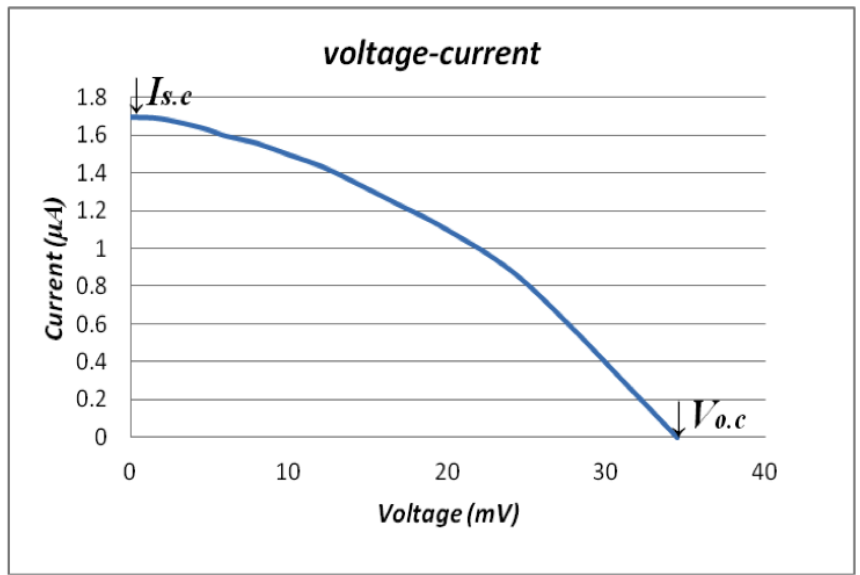

Figure 3: I-V characteristic of shaded solar panels (two series cells shaded).

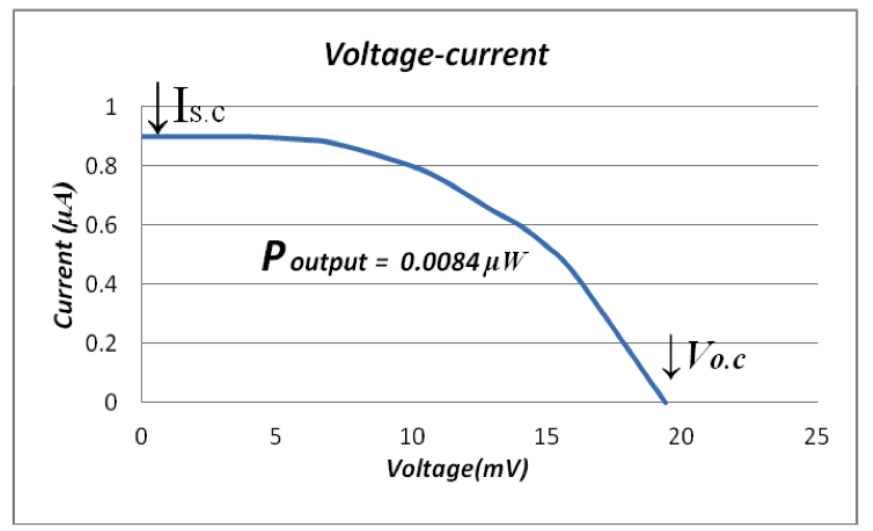

Figure 4: $I-V$ characteristic of shaded solar panels (four series cells shaded). 


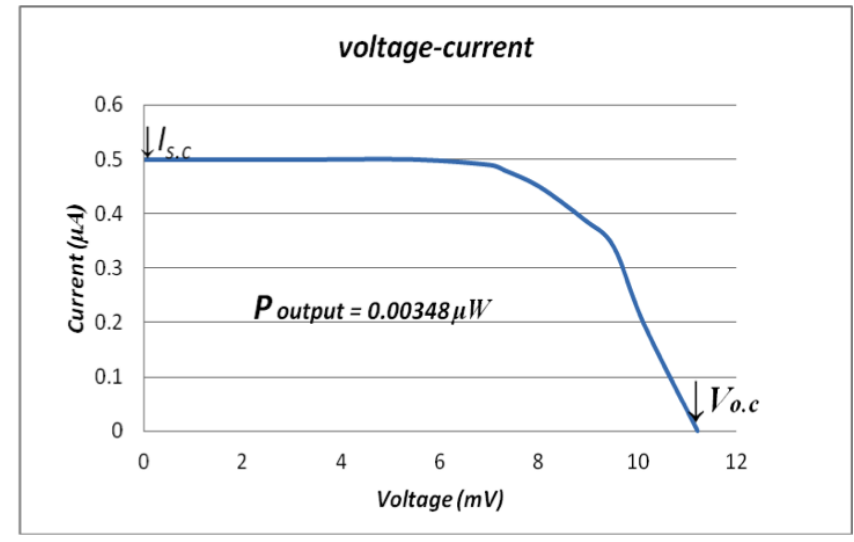

Figure 5: $I-V$ characteristic of shaded solar panels (six series cells shaded).

By shading more series cells, say four cells, the $V_{o c}$ was decreased to $9.4 \mathrm{mV}$, while the $I_{s c}$ and $P_{\text {out }}$ were decreased to $0.9 \mu \mathrm{A}$ and $0.0084 \mu \mathrm{W}$, respectively. In order to further investigate the photovoltaic performance of the panels under partial shading, and understand their behaviors, six series cells were also shaded. We noticed that by increasing the area of series shading, the photovoltaic parameters were decreased dramatically, such that the $V_{o c}, I_{s c}$, and $P_{\text {out }}$ were decreased to $11.2 \mathrm{mV}, \quad 0.5 \mu \mathrm{A}$ and $3.48 \mathrm{nW}$, respectively.

In real situations, the cells that are facing partial shading may be among those with parallel interconnected cells of the panel, making the parallel shading investigation crucial. Figures 6 and 7 show the photovoltaic performance of parallel shaded solar panels with each parallel shaded string composed of five series cells (see Figure 1). By shading one parallel string (made of five cells), the value of open circuit voltage, short circuit current and output power were decreased to $27 \mathrm{mV}, 1.3 \mu \mathrm{A}$ and $0.02016 \mu \mathrm{W}$, respectively. One can see from Figure 6 that despite decrement in the performance there is a less considerable deviation in the shape of the $I-V$ curve. The approximate rectangular shape of the curve is close enough to that of the non-shaded solar panels. This is ascribed to the fact that only parallel cells have been shaded, which gives rise to the change in the parallel internal resistance of the panel instead of the series resistance. As such, the current can find the non-shaded cells and does not pass through the parallel shaded cells. Noteworthy, upon shading two parallel strings (two columns of cells), the photovoltaic characteristics showed highly decreased value of the panels parameters; $V_{o c}=10.5 \mathrm{mV}, I_{s c}=0.4 \mu \mathrm{A}$ and $\mathrm{P}_{\text {out }}=$ $2.26 \mathrm{nW}$.

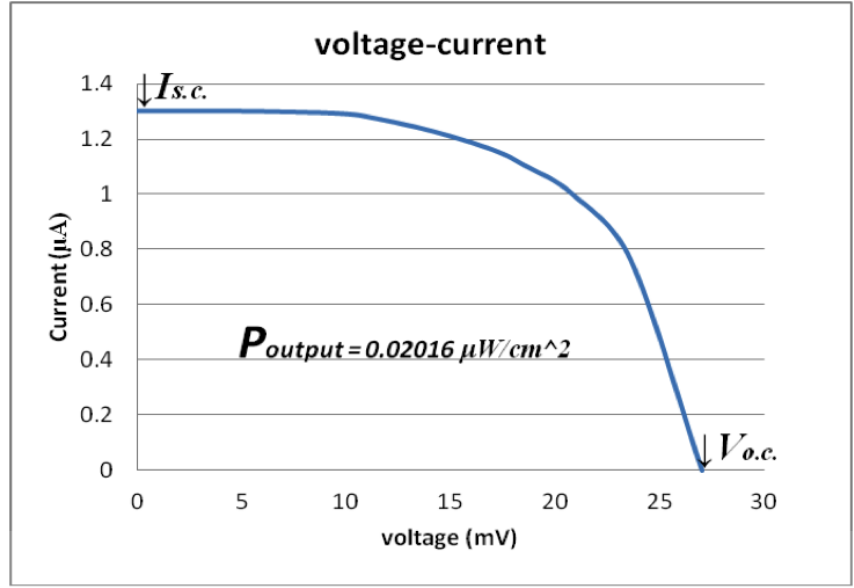

Figure 6: $I-V$ characteristics of shaded solar panel (five parallel cells shaded).

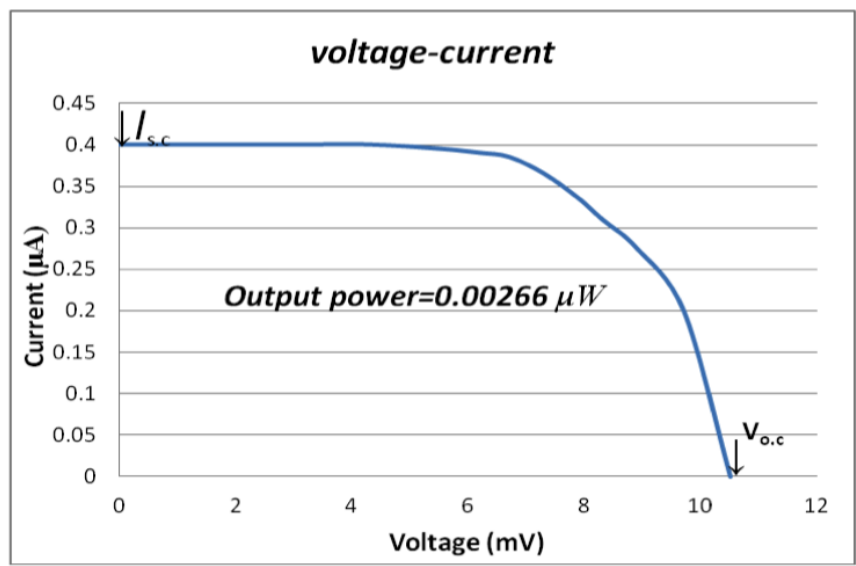

Figure 7: I-V characteristics of shaded solar panel (ten parallel cells shaded).

Figure 8 shows the variation of maximum power that is capable to be generated by the solar panels against the parallel and series shading of the cells. Noticeably, the decrement of power due to series shading is more prominent compared to that of the parallel shading. One can see from the figure that the parallel shading of one string, which is equivalent to five series cells, has made the panels power to decrease less compared to those of the two or four series shading. It is however clear that the number of shaded cells in the parallel situation is more than those of series shading, but the photovoltaic performance in the parallel shading is still better compared to those of the series shadings. This is attributed to the adverse effect of the series resistance of the shaded cells, which is acted as a bottleneck in front of the passage of current. This is not very effective in the parallel shading because current is readily capable to pass through the illuminated parallel cells and neglect the pathway of parallel shaded cells. 


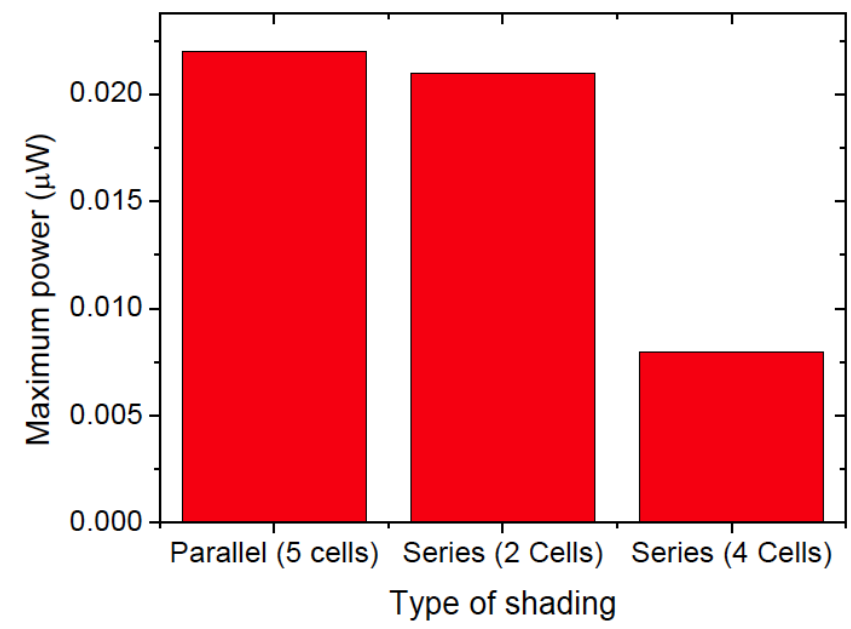

Figure 8: Maximum power versus type of shading for solar panels under partial shading.

Table 1 tabulates the variation of maximum power and fill factor of the solar panels upon shading. It was observed that by increasing the shading of solar cells in parallel from one string to two strings, the fill factor was decreased. In contrast to this, the fill factor was seen to increase when the series shading is enlarged. This may be because of that by increasing the series shading area from two cells to four cells, only one cell remains in the string line ( 5 series cells) to participate in the photoelectric generation, which in turn acts upon reducing the impact of large current passage through the rest of the four shaded cells.

Table 1: Maximum Power and Fill Factor Records for the Series and Parallel Shaded Solar Panels

\begin{tabular}{|c|c|c|}
\hline Shading Condition & $\begin{array}{c}\text { Maximum Power, } \\
\text { Pmax }(\mu \mathbf{W})\end{array}$ & $\begin{array}{c}\text { Fill factor } \\
(\mathrm{FF}) \%\end{array}$ \\
\hline \hline Parallel (5 cells/1string) & 0.022 & 62.8 \\
\hline Parallel (10 cells/2 strings) & 0.002 & 50.0 \\
\hline Series (2 cells) & 0.021 & 35.8 \\
\hline Series (4 cells) & 0.008 & 47.05 \\
\hline
\end{tabular}

\section{CONCLUSIONS}

Investigation on the impact of series and parallel shading on the photovoltaic performance of inorganic solar cells based on silicon wafers has been carried out. It was seen that beyond a specific voltage, where the maximum power can be delivered to the load, the current starts to decrease rapidly. This current decrement is due to the high output load resistance in comparison to that of the internal resistance of the solar panel. The I-V curve of shaded panels was different from that of the non-shaded solar panel, indicating the effect of series shading on the performance of the panel. Results showed that the number of shaded cells in the parallel situation was however more than those of series shading, but the photovoltaic performance in the parallel shading was still better compared to those of the series shadings. This was attributed to the adverse effect of the series resistance of the shaded cells, which is acted as a bottleneck in front of the passage of current. This was not very effective in the parallel shading because current is readily capable to pass through the illuminated parallel cells and neglect the pathway of parallel shaded cells.

\section{ACKNOWLEDGEMENT}

The authors are thankful to the Department of Physics, Koya University for the administrative support to this work.

\section{CONFLICT OF INTEREST}

The authors declare that there is no conflict of interests regarding the publication of this article.

\section{REFERENCES}

[1] Wright M, Uddin A. Organic-inorganic hybrid solar cells: A comparative review. Solar Energy Materials and Solar Cells 2012; 107: 87-111 http://dx.doi.org/10.1016/j.solmat.2012.07.006

[2] Aberle AG. Thin-film solar cells. Thin Solid Films 2009; 517: 4706-10. http://dx.doi.org/10.1016/j.tsf.2009.03.056

[3] Muhammad FF. Design approaches to improve organic solar cells. Journal of Technology Innovations in Renewable Energy 2014; 3: 1-8.

http://dx.doi.org/10.6000/1929-6002.2014.03.02.4

[4] Parida B, Iniyan S, Goic R. A review of solar photovoltaic technologies. Renewable and Sustainable Energy Reviews 2011; 15: 1625-36. http://dx.doi.org/10.1016/j.rser.2010.11.032

[5] Candela R, Dio VD, Sanseverino ER, Romano P. Reconfiguration techniques of partial shaded PV systems for the maximization of electrical energy production. Clean Electrical Power, 2007 ICCEP'07 International Conference on: IEEE 2007; pp. 716-9. http://dx.doi.org/10.1109/iccep.2007.384290

[6] Sabry M, Ghitas AE. Effect of edge shading on the performance of silicon solar cell. Vacuum 2006; 80: 444-50. http://dx.doi.org/10.1016/j.vacuum.2005.07.012

[7] Gao L, Dougal R, Liu S, lotova AP. Parallel-connected solar PV system to address partial and rapidly fluctuating shadow conditions. Industrial Electronics, IEEE Transactions on 2009; 56: 1548-56. http://dx.doi.org/10.1109/TIE.2008.2011296

[8] Ramabadran R, Mathur B. Matlab based modelling and performance study of series connected SPVA under partia shaded conditions. Journal of Sustainable development 2009; 2: 85.

[9] Ramabadran R, Mathur B. Effect of shading on series and parallel connected solar PV modules. Modern Applied Science 2009; 3: 32.

http://dx.doi.org/10.5539/mas.v3n10p32 
[10] Seyedmahmoudian M, Mekhilef S, Rahmani R, Yusof R, Renani E. Analytical Modeling of Partially Shaded Photovoltaic Systems. Energies 2013; 6: 128. http://dx.doi.org/10.3390/en6010128

[11] Salvadores C, Francisco J. Shadowing Effect On The Performance In Solar Pv-Cells [MSc]. Faculty of Engineering and Sustainable Development University of Gavle 2015.

[12] Muhammad FF, Sulaiman K. Photovoltaic performance of organic solar cells based on DH6T/PCBM thin film active layers. Thin Solid Films 2011; 519: 5230-3. http://dx.doi.org/10.1016/j.tsf.2011.01.165

[13] Esram T, Chapman PL. Comparison of photovoltaic array maximum power point tracking techniques. IEEE Transactions on Energy Conversion EC 2007; 22: 439. http://dx.doi.org/10.1109/TEC.2006.874230
$[14]$

Salas V, Olias E, Barrado A, Lazaro A. Review of the maximum power point tracking algorithms for stand-alone photovoltaic systems. Solar energy materials and solar cells 2006; 90: 1555-78.

http://dx.doi.org/10.1016/j.solmat.2005.10.023

[15] Han L, Koide N, Chiba Y, Islam A, Komiya R, Fuke N, et al. Improvement of efficiency of dye-sensitized solar cells by reduction of internal resistance. Applied Physics Letters 2005; 86: 213501.

http://dx.doi.org/10.1063/1.1925773

[16] Muhammad FF. Impedance spectroscopy analysis of DH6T: PCBM bulk heterojunction incorporating Gaq3: experiment and model. J Mater Sci Mater Electron 1-8. 